\title{
EFFECT OF PRETREATMENTS ON CHEMICAL AND ANTIOXIDANT PROPERTIES OF SKY FRUIT (Swietenia macrophylla) SEED OIL
}

\author{
[Pengaruh Pra-perlakuan Terhadap Sifat Kimia dan Antioksidan \\ Minyak Biji Buah Tunjuk Langit (Swietenia macrophylla)] \\ Lau Chiew Ping, Nor Hayati Ibrahim* and Hayati Mohd Yusof \\ Food Science Department, Faculty of Agrotechnology and Food Science, University Malaysia Terengganu, \\ 21030 Kuala Terengganu, Terengganu, Malaysia
}

Accepted November $14^{\text {th }} 2012$ / Approved December $13^{\text {th }} 2012$

\begin{abstract}
The objective of this study was to investigate the effect of pretreatments on chemical and antioxidant properties of sky fruit (Swietenia macrohylla) seed oil. The seeds were treated with different heat pretreatments (roasting, steaming, and microwaving) and subsequently subjected to oil extraction by using a Bligh and Dyer method. It was found that different pretreatments significantly $(p<0.05)$ affected yield and peroxide value of the extracted oils. However, no significant effect of pretreatment was observed on free fatty acid content of the seed oils. The oils exhibited significantly different levels of 1, 1-diphenyl-2-picrylhydrazyl (DPPH) scavenging activity due to different heat pretreatments. The results revealed that the mean percentages of DPPH scavenging activity of untreated (control) seed oil (87.69\%) and steamed seed oil $(83.40 \%)$ were significantly higher than those of roasted seed oil $(75.71 \%)$ as well as the microwaved one $(63.98 \%)$. In contrast, the pretreatments did not significantly affect total phenolic content (TPC) of the seed oils with the TPC mean values ranging from 0.016 to $0.022 \mathrm{mg} / \mathrm{g}$ (as gallic acid). Data gained from this study provided valuable information for edible oil industries in searching for alternative source of edible oil with medicinal benefits.
\end{abstract}

Keywords: antioxidant, microwaving, roasting, seed oils, sky fruit, steaming

\section{ABSTRAK}

Tujuan penelitian ini adalah mengetahui pengaruh perlakuan pendahuluan terhadap sifat kimia dan antioksidan minyak biji buah tunjuk langit (Swietenia macrohylla). Biji diberi beberapa perlakuan pendahuluan panas yang berbeda (pemanggangan, pengukusan, dan pemanasan microwave), kemudian diekstraksi minyaknya menggunakan metode Bligh dan Dyer. Perlakuan pendahuluan yang berbeda memberikan perbedaan signifikan $(p<0,05)$ terhadap rendemen dan nilai peroksida dari minyak yang diekstrak. Namun, perlakuan pendahuluan tidak memberikan pengaruh yang signifikan terhadap kandungan asam lemak bebas minyak biji. Minyak menunjukkan tingkat signifikansi yang berbeda terhadap scavenging activity 1, 1-difenil-2-pikrilhidrazil (DPPH) karena perlakuan pendahuluan panas yang berbeda. Hasil penelitian menunjukkan bahwa persentase rata-rata scavenging activity DPPH dari minyak biji kontrol (87,69\%) dan minyak biji yang dikukus (83,40\%) jauh lebih tinggi dibandingkan dengan dari minyak biji panggang $(75,71 \%)$ serta minyak biji microwave (63,98\%). Sebaliknya, perlakuan pendahuluan tidak secara signifikan mempengaruhi kandungan fenolik total (TPC) dari minyak biji dengan nilai rata-rata TPC berkisar 0,016 sampai 0,022 mg/g (sebagai asam galat). Data yang diperoleh dari studi ini memberikan informasi yang penting untuk industri minyak makan dalam mencari sumber alternatif minyak nabati yang mempunyai manfaat terhadap kesehatan.

Kata kunci: antioksidan, perlakuan microwave, pemanggangan, minyak biji, buah langit, pengukusan

\section{INTRODUCTION}

Swietenia macrophylla or big leaf mahogany is a tree from family Meliaceae. Swietenia macrophylla's wood, leaves and fruits can be used for many purposes (Falah et al., 2008). Swietenia macrophylla produces a fruit that commonly known as sky fruit, because the fruit seems to point upwards to the sky. Sky fruit has been processed commercially to a wide range of health foods and healthcare products. Besides, sky fruit was

Paper was Presented at International Conference on "Future of Food Factors", October 3-4, 2012, Jakarta, Indonesia.

${ }^{*}$ Corresponding Author:

Email: yati@umt.edu.my; Phone : +609-6683644 used as an old folk medicine for treatment of diabetes and hypertension by chewing and then swallowing the seeds. Sky fruit seed was reported to contain different types of limonoids such as swietenine, swietenine acetate and anti-diabetic, antimicrobial, antidiarrhoeal benefits (Chen et al., 2010; Maiti et al., 2008; Falah et al., 2008; Maiti et al., 2007). The seed is rich in fat content and swietenolide, a bitter principle (Chakrabarty and Chowdhuri, 1956). Apart from that, the seed oil consisted of six types of fatty acid which included palmitic acid $(12.50 \%)$, stearic acid $(16.42 \%)$, arachidic acid $(0.56 \%)$, oleic acid (25.30\%), linoleic acid (33.87\%) and linolenic acid (11.32\%) (Chakrabarty and Chowdhuri, 1956). The abundance of polyunsaturated fatty acid (PUFA) especially linoleic and oleic acids shows that sky fruit seed oil has the ability to provide benefit to 
human health. However, little attention has been paid on the information of PUFA in sky fruit seed. PUFA is known to be highly prone to oxidation. Oxidation of oil produces rancid flavour and decreases quality of oil. Different heat pretreatments used in industry such as roasting, microwaving and steaming might provide different effects on the seed oil quality. Previously, it has been found that roasting could provide better resistance for honeydew seed oil towards oxidative deterioration (Chin, 2012). Microwaving pretreatment and steaming pretreatment increased the yield and quality of seed oil (Uquiche et al., 2008; Danso-Boateng, 2011). To this far, the effect of heat pretreatments on sky fruit seed oil is yet to be studied. Therefore, this study was conducted to investigate the effect of pretreatments on chemical and antioxidant properties of sky fruit seed oils.

\section{MATERIALS AND METHODS}

\section{Sample preparation}

$100 \mathrm{~g}$ of sky fruit seeds (each batch) after roasting by using convection oven (model Master 450, Garland, Freeland, Pennsylvania) at $200^{\circ} \mathrm{C}$ for 20 minutes, steaming at $100^{\circ} \mathrm{C}$ for 20 minutes, or microwaving by using micro oven (model Dimension 4, The Genius, National, Japan) at $2450 \mathrm{MHz}$ for 15 minute were used to prepare the sky fruit seed oils.

\section{Extraction of oil}

The oils from untreated (control) and treated seeds were extracted by using a Bligh and Dyer method with a slight modification. $100 \mathrm{~g}$ of sky fruit seeds were mixed with solvent of methanol $(200 \mathrm{ml})$ and chloroform $(100 \mathrm{ml})$ in a ratio of $2: 1$. The mixture was finely grounded by using Waring blender (Waring Commercial, HGB2WTS3, USA). The mixtures were filtered to separate the seeds and solvent. Same amount of methanol and chloroform solvent were mixed filtered seeds. Next, the mixture was transferred into a blue capped bottle and agitated by using an incubator shaker (model Innova 40R, USA) at rpm 200 at $25^{\circ} \mathrm{C}$ for an hour. After the agitation process, the mixture was filtered to separate the seeds and solvent. The agitation and filtering process were conducted consistently until a clear solvent was obtained from the residual seeds. The mixture of solvent and oil was evaporated by using rotary evaporator (model N-1000, Eyela, Tokyo Rikakikai Co. Ltd., Tokyo, Japan) at $65^{\circ} \mathrm{C}$ until almost all solvents were evaporated. The oil obtained after evaporation was centrifuged (model Hettich Zentrifugen Universal 32, Germany) at rpm 4000 for 10 minutes. The supernatant of oil layer was stored at $-20^{\circ} \mathrm{C}$ for further analysis (Yanty et al., 2008; modified by Chin, 2012).

\section{Free fatty acid (FFA)}

$1 \mathrm{~g}$ of oil was dissolved with $25 \mathrm{ml}$ diethyl ether with $25 \mathrm{ml}$ alcohol and $1 \mathrm{ml} 1 \%$ phenolphthalein solution. The solution was titrated with aqueous $0.1 \mathrm{M}$ of sodium hydroxide by shaking continuously until pink colour solution which persists for 15 seconds was formed. The amount of aqueous $0.1 \mathrm{M}$ of sodium hydroxide used was recorded. The free fatty acid value was calculated as follows: Free fatty acid as oleic acid $\%=($ volume of titration x normality of $\mathrm{NaOH} \times 28.2$ )/weight of sample (AOCS, 1976).

\section{Peroxide value (PV)}

Peroxide value defined as the miliequivalents of active oxygen per kilogram of oil (meq $\mathrm{O}_{2} / \mathrm{kg}$ ) was determined. $1 \mathrm{~g}$ of oil was weighed in a $250 \mathrm{ml}$ conical flask and dissolved with 10 $\mathrm{ml}$ of chloroform and $15 \mathrm{ml}$ of acetic acid at a ratio of $2: 3.1 \mathrm{ml}$ of concentrated potassium iodide was added and kept in dark for 5 minutes. After 5 minutes, $75 \mathrm{ml}$ of distilled water was added. Then, $1 \mathrm{ml}$ of $2 \%$ starch indicator was added and the mixture was titrated with $0.01 \mathrm{~N}$ sodium thiosulphate till colorless end point. The blank sample was conducted without sample. The peroxide value was determined as [(volume of titration of sample - volume of titration of blank) $x$ normality of $\mathrm{Na}_{2} \mathrm{~S}_{2} \mathrm{O}_{3} \times 1000$ ]/weight of oil (modified from Egan et al., 1990).

\section{Free radical scavenging activity (DPPH)}

1,1-diphenyl-2-picrylhydrazyl (DPPH) free radical was used to measure the antioxidant activity of sky fruit seed oil. $3 \mathrm{ml}$ of oil extract in methanol $(300 \mathrm{mg} / \mathrm{ml})$ was mixed with $3 \mathrm{ml}$ of methanolic solution containing DPPH radicals $(0.2 \mathrm{mM})$. The mixture was vortexed (model MS1 minishaker, IKA Works, Guangzhou) for 1 minute at $2000 \mathrm{rpm}$ and allowed to stand for 30 minutes in the dark. After 30 minutes, the absorbance was read against a blank by using a spectrophotometer (model 4001/4, GENESYS 20 Thermospectronic, Thermo Electron Corp., USA) at $517 \mathrm{~nm}$. Percentage inhibition activity (\%) was calculated as [(absorbance of control-absorbance of sample) labsorbance of control] x 100\%. $\alpha$-tocopherol was used as reference compound and was found to exhibit $74.65 \pm 2.13 \%$ inhibition of DPPH radical activity (modified from Marina et al., 2008).

\section{Total phenolic content (TPC)}

The total phenolic content in the methanolic extracts was determined by the Folin-Ciocalteu method by Singleton and Rossi. $2 \mathrm{~g}$ of oil was measured into a test tube and then $6.0 \mathrm{ml}$ of methanol was added. The test tube was vortexed (model MS1 minishaker, IKA Works, Guangzhou) and then centrifuged (Hettich Zentrifugen Universal 32, Germany) at 3000 rpm for 10 minutes and the supernatant was collected. This procedure was repeated twice. All the three extractions were combined and the final volume was made up to $20 \mathrm{ml}$ with methanol. $0.1 \mathrm{ml}$ aliquot of methanolic extract was placed in a volumetric flask $(10 \mathrm{ml})$. $0.5 \mathrm{ml}$ of Folin-Ciocalteau was added. 3 minutes later, $1.5 \mathrm{ml}$ of saturated sodium carbonate was added. The flask was filled with water up to $10 \mathrm{ml}$. After 2 hours reaction at room temperature, the absorbance was read at $765 \mathrm{~nm}$ by using a spectrophotometer (model 4001/4, GENESYS 20 Thermospectronic, Thermo Electron Corp., USA). Gallic acid was used as the standard in the range 0 to $500 \mathrm{mg} / \mathrm{L}$ (modified from Malacrida and Jorge, 2012). The total phenolic content of extract was calculated and expressed in gallic acid equivalent (mg GAE/g). 


\section{Experimental design and data analysis}

Experiments were arranged based on a completely randomized design with a one-way treatment structure. A oneway ANOVA with Tukey's Multiple Comparisons statistical analysis was applied on a triplicate data in order to determine any significant differences at at level of $p<0.05$ using a Minitab (Release 16) (Minitab Inc., USA) statistical software package.

\section{RESULTS AND DISCUSSION}

\section{Seed oil yield}

The yield of sky fruit seed oil with different pretreatments is shown in Table 1. The oil yield from microwaved sky fruit seed was $29.50 \%$ and significantly $(p<0.05)$ different from roasting and steaming seed oils. Microwaving pretreatment showed the highest oil yield compared to roasting, steaming and untreated sky fruit seeds. Microwave heating vapourizes the water of the seed microstructure and increasing its interior pressure which leads to cell membrane rupture. Thus, efficiency of the extraction of oil from oil seeds was improved by enabling the passage of oil from the cell membrane (Uquiche et al., 2008). In a study of microwaved hazelnut seeds indicated that microwave pretreatment affected cell walls and membrane cell and obtained high extraction yield of oils compared to untreated hazelnut seeds (Uquiche et al., 2008). The rupture of cell membrane resulted in permanent pores which allowing the oil to move through the permeable cell walls (Azadmard-Damirchi et al., 2010). Oil yield of roasting pretreatment sky fruit seed was $24.82 \%$ which was lower than the oil yield from untreated seed $(28.46 \%)$. However, previous studies showed that roasted cashew nut and roasted honeydew seed have high oil yield compared to untreated cashew nut and untreated honeydew seed (Chandrasekara and Shahidi, 2011; Chin, 2012). Steamed sky fruit seed showed the lower oil yield which was $23.29 \%$. Similar trend also found in steamed honeydew seed. The oil yield of steamed honeydew seed was $14.97 \%$ lower than microwaved honeydew seed $(18.85 \%)$ and roasted honeydew seed $(21.59 \%)$. This was due to the increase of moisture in the seed during steaming which caused difficulty in filtration to separate the seed with solvent. Some of the oil was lost during extraction process (Chin, 2012).

Table 1. Yield of sky fruit seed oil with different seed pretreatments

\begin{tabular}{cc}
\hline Pretreatment & Yield $(\%)$ \\
\hline Control & $28.46 \pm 0.88^{\mathrm{a}}$ \\
Microwaving & $29.50 \pm 1.64^{\mathrm{a}}$ \\
Roasting & $24.82 \pm 1.10^{\mathrm{b}}$ \\
Steaming & $23.29 \pm 1.41^{\mathrm{b}}$ \\
\hline
\end{tabular}

Values are mean \pm standard deviation from three replications $(n=3)$

Values with different superscripts letter are significantly different at $p<0.05$

\section{Free fatty acid (FFA)}

There was no significant different on free fatty acid between untreated fresh sky fruit seed oil with other sky fruit seed oils in different pretreatments. The free fatty acid content of extracted oils was in the range of $1.48-1.85 \%$ as shown in Table 2 . The free fatty acid content in this study was higher than Chakrabarty and Chowdhuri's study (1956) which was $0.6 \%$. Roasting and steaming pretreatments seed oil $(1.63 \%$ and $1.85 \%$ respectively) showed higher free fatty acid compared to untreated fresh sky fruit seed oil (1.57\%) and microwaving seed oil $(1.48 \%)$. High value of free fatty acid in oil from roasted seed and steamed seed were due to greater liberation of free fatty acids affected by heat application (Oneya et al., 2005). Microwaving pretreatment sky fruit seed oil showed the lowest free fatty acid value $(1.48 \%)$. It was due to inactivation of lipolytic enzyme by microwave heat (Thanonkaew et al., 2012). The lower the free fatty acid value, the better the storage and shelf life of the oil will be (Jafari et al., 2012).

Table 2. Free fatty acid of sky fruit seed oil with different seed pretreatments

\begin{tabular}{cc}
\hline Pretreatment & Free Fatty Acid (\% in Oleic Acid) \\
\hline Control & $1.57 \pm 0.17^{\mathrm{a}}$ \\
Microwaving & $1.48 \pm 0.16^{\mathrm{a}}$ \\
Roasting & $1.63 \pm 0.04^{\mathrm{a}}$ \\
Steaming & $1.85 \pm 0.16^{\mathrm{a}}$ \\
\hline
\end{tabular}

Values are mean \pm standard deviation from three replications $(n=3)$

\section{Peroxide value (PV)}

Table 3 depicts the peroxide value of sky fruit seed oil with different seed pretreatments. Peroxide value of steaming pretreatment sky fruit seed oil was $1.85 \mathrm{meq} \mathrm{O}_{2} / \mathrm{kg}$ and significantly $(p<0.05)$ different with untreated, roasting, and microwaving seed oils. Steaming pretreatment sky fruit seed oil has the lowest peroxide value which was $1.98 \mathrm{meq} \mathrm{O}_{2} / \mathrm{kg}$. The peroxide value of fresh steamed sky fruit seed oil was not much different with fresh steamed honeydew seed oil (1.93 meq $\mathrm{O}_{2} /$ $\mathrm{kg}$ ) (Chin, 2012). Peroxide value for microwaving pretreatment sky fruit seed oil was $2.96 \mathrm{meq} \mathrm{O}_{2} / \mathrm{kg}$ which higher than untreated seed oil $\left(2.61 \mathrm{meq} \mathrm{O}_{2} / \mathrm{kg}\right)$. The high peroxide value was due to the presence of reactive radicals that formed by exposure to microwaves (Uquiche et al., 2008). Roasting pretreatment sky fruit seed oil has the highest free fatty acid which was $3.25 \mathrm{meq} \mathrm{O}_{2} / \mathrm{kg}$. Previous study showed that roasted seed decreased the peroxide value due to the non enzymatic reaction and caramelization products formed during roasting. Maillard reaction products formed through the interaction of proteins and reducing sugars helps in reducing the peroxide value in roasted seed oil (Lee et al., 2004). However, the finding was in contrast with the present finding.

Table 3. Peroxide value of sky fruit seed oil with different seed

\begin{tabular}{cc} 
pretreatments & \\
\hline Pretreatment & Peroxide Value $\left(\mathrm{meq} \mathrm{O}_{2} / \mathrm{kg}\right)$ \\
\hline Control & $2.61 \pm 0.55^{\mathrm{ab}}$ \\
Microwave & $2.96 \pm 0.03^{\mathrm{ab}}$ \\
Roasting & $3.25 \pm 0.53^{\mathrm{a}}$ \\
Steaming & $1.98 \pm 0.01^{\mathrm{b}}$ \\
\hline
\end{tabular}

Values are mean \pm standard deviation from three replications $(n=3)$

Values with different superscripts letter are significantly different at $p<0.05$

\section{Free radical scavenging activity (DPPH)}

Results of the present study showed that percentage of inhibition activity of untreated sky fruit seed oil (87.69\%) was significantly $(p<0.05)$ higher than roasted sky fruit seed oil $(75.71 \%)$ and microwaved sky fruit seed oil $(63.98 \%)$ but not 
significantly difference from steamed sky fruit seed oil (Table 4). The result revealed that heat treatment did not increase the percentage of inhibition activity in the oil. From previous study, roasted sesame seed oil has high antioxidant activity compared to raw sesame seed oil due to the formation of sesamol from the degradation of sesaminol (Jannat et al., 2010). However, sesamol does not present in the sky fruit seed.

Table 4. Inhibition of DPPH radical activity (\%) of sky fruit seed oil with different seed pretreatments

\begin{tabular}{cc}
\hline Pretreatment & Inhibition of DPPH Radical Activity $(\%)$ \\
\hline Control & $87.69 \pm 2.46^{\mathrm{a}}$ \\
Microwave & $63.98 \pm 2.75^{\mathrm{c}}$ \\
Roasting & $75.71 \pm 3.43^{\mathrm{b}}$ \\
Steaming & $83.40 \pm 2.09^{\mathrm{a}}$ \\
\hline
\end{tabular}

Values are mean \pm standard deviation from three replications $(n=3)$

Values with different superscripts letter are significantly different at $p<0.05$

\section{Total phenolic content (TPC)}

Table 5 shows the total phenolic content of sky fruit seed oil with different seed pretreatments. There was no significant different between untreated sky fruit seed oil with other sky fruit seed oils in terms of total phenolic content. Steaming pretreatment on sky fruit seed oil achieved the highest total phenolic content with the value $0.022 \mathrm{mg} \mathrm{GAE} / \mathrm{g}$. Untreated sky fruit seed oil had a similar total phenolic content with microwaved sky fruit seed oil which was $0.017 \mathrm{mg} \mathrm{GAE} / \mathrm{g}$. Roasting pretreatment sky fruit seed oil had the lowest total phenolic content which only $0.016 \mathrm{mgGAE} / \mathrm{g}$. The total phenolic content for roasting seed oil seemed to be not much different from the total phenolic content for microwaving and untreated seed oil. Phenolic compounds are desirable in edible oils, but only a small amount of phenolic compounds are transferred to the oil (Vujasinovic et al., 2012). Steaming pretreatment on sky fruit seed oil showed increased of total phenolic content compare to untreated seed oil. The increasing in total phenolic content might due to the result from the transformation of bound to free polyphenols by the heat treatment and the formation of high-molecular weight phenolic compounds or the production of new phenolic compounds (Bae et al., 2012).

Table 5. Total phenolic content of sky fruit seed oil with different seed pretreatments

\begin{tabular}{cc}
\hline Pretreatment & Total phenolic content $(\mathrm{mg} \mathrm{GAE} / \mathrm{g})$ \\
\hline Control & $0.017 \pm 0.004^{\mathrm{a}}$ \\
Microwave & $0.017 \pm 0.002^{\mathrm{a}}$ \\
Roasting & $0.016 \pm 0.001^{\mathrm{a}}$ \\
Steaming & $0.022 \pm 0.002^{\mathrm{a}}$ \\
\hline
\end{tabular}

Values are mean \pm standard deviation from three replications $(n=3)$

\section{CONCLUSION}

This study documented the influence of different pretreatments namely roasting, steaming, and microwaving on chemical and antioxidant properties of sky fruit seed oils. Different pretreatments significantly affected yield, peroxide value and free radical scavenging activity of the extracted oils. However, no significant effect of pretreatments was reported on free fatty acid and total phenolic content. Eventhough steamed sky fruit seed produced low yield of oil, it desirably possessed low free fatty acid value and high inhibition activity towards free radical and high total phenolic content.

\section{ACKNOWLEDGEMENT}

This study was partially funded by Ministry of Higher Education (Malaysia) under the FRGS Grant No. 59211.

\section{REFERENCES}

[AOCS] American Oil Chemistry Society. 1976. Official method Ca 5a-40. Free fatty acid. J Assoc Anal Chem 59: 658.

Azadmard-Damirchi S, Habibi-Nodeh F, Hesari J, Nemati M, Achachlouei BF. 2010. Effect of pretreatment with microwaves on oxidative stability and nutraceuticals content of oil from rapeseed. Food Chem 12: 1211-1215. DOI: 10.1016/j. foodchem.2010.02.006.

Bae HM, Kim SS, Cho CW, Yang DC, Ko SK, Kim KT. 2012. Antioxidant activities of ginseng seeds treated by autoclaving. J Ginseng Res 36:411-417. DOl: 10.5142/jgr.2012.36.4.411.

Chakrabarty MM, Chowdhuri DK. 1956. The fatty acid composition of the seed fat from Swietenia macrophylla. J Am Oil Chem 34: 489-490.

Chandrasekara N, Shahidi F. 2011. Oxidative stability of cashew oils from raw and roaste nuts. J Am Oil Chem 88: 1197-1202. DOI: 10.1007/s11746-011-1782-3.

Chen JJ, Huang SS, Liao CH, Wei DC, Sung PJ, Wang TC, Cheng MJ. 2010. A new phargmalin-type limonoid and antiinflammatory constituents from the fruits of Swietenia macrophylla. Food Chem 120:379-384. DOl: 10.1016/j.foodchem.2009.09.093.

Chin AC. 2012. Effects of Pretreatments on Lipid Oxidation Stability of Honeydew (Cucumis melo) Seed Oil. Undergraduate. [Thesis] Faculty of Agrotechnology and Food Science, University Malaysia Terengganu, Terengganu.

Danso-Baoteng E. 2011. Effect of enzyme and heat pretreatment on sunflower oil recovery using aqueous and hexane extractions. Eng Technol 80: 839-845.

Egan H, Kirk RS, Sawyer R. 1990. Pearson Chemical Analysis of Foods. $8^{\text {th }}$ ed. 536. Longman Group and Technical, London.

Falah S, Suzuki T, Katayama T. 2008. Chemical Constituents from Swietenia macrophylla bark and their antioxidant activity. J Biol Sci 11: 2007-2012.

Jafari M, Goli SAH, Rahimmalek M. 2012. The chemical composition of the seeds of Iranian pumpkin cultivars and physicochemical characteristics of the oil extract. Eur J Lipid Sci Technol 114: 161-167. DOI: 10.1002/ejlt.201100102.

Jannat B, Oveisi MR, Sadeghi N, Hajimahmoodi M, Behzad M, Choopankari E, Behfar AA. 2010. Effects of roasting temperature and time on healthy nutraceuticals of 
antioxidants and total phenolic content Iranian sesame seeds (Sesamun indicum L.). Iran J Environ Health Sci Eng 7: 97-102.

Lee YC, Kim IH, Chang J, Rhee YK, Oh HI, Park HK. 2004. Chemical composition and oxidative stability of safflower oil prepared with expeller from safflower seeds roasted at different temperatures. J Food Sci 69: 33-38. DOl: 10.1111/ j.1365-2621.2004.tb17852.x.

Maiti A, Mandal SC, Dewanjee S. 2007. In vivo evaluation of antidiarrhoel activity of the seed of Swietenia macrophylla King (Meliaceae). J Pharm Res 6: 711-716.

Maiti A, Dewanjee S, Jana G, Mandal SC. 2008. Hypoglycemic effect of Swietenia macrophylla seeds against type II diabetes. Int J Green Pharm 2: 224-227. DOI: 10.4103/ 0973-8258.44738.

Malacrida CR, Jorge N. 2012. Yellow passion fruit seed oil (Passiflora edulis f. flavicarpa): physical and chemical characteristics. Braz Arch Biol Technol 55: 127-134. DOl: 10.1590/S1516-89132012000100016.

Marina AM, Che Man YB, Nazimah SAH, Amin I. 2008. Antioxidant capacity and phenolic acids of virgin coconut oil. Int J Food Sci Nutr 60: 114-123. DOl: 10.1080/09637480802549127.
Oneya EU, Onuegbu N, Onuaha NU, Ochonogor F. 2005. Effect of extraction pretreatment on the composition and characteristics of seed and pulp oil of African Black Pear (Dacryodes edulis). Nigerian Food J 23: 13-20.

Thanonkaew A, Wongyai S, McClements DJ, Decker EA. 2012. Effect of stabilization of rice bran by domestic heating on mechanical extraction yield, quality, and antioxidant properties of cold-pressed rice bran oil (Oryza saltiva L.). LWT Food Sci Technol 48: 231-236. DOl: 10.1016/j.Iwt.2012.03.018.

Uquiche $\mathrm{E}$, Jerez M, Ortiz J. 2008. Effect of pretreatment with microwaves on mechanical extraction yield and quality of vegetable oil from Chilean hazelnuts (Gevuina avellana Mol). Innov Food Sci Emerg 9: 495-500. DOl: 10.1016/j.ifset.2008.05.004.

Vujasinovic V, Djilas S, Dimic E, Basic Z, Radocaj O. 2012. The effect of roasting on the chemical composition and oxidative stability of pumpkin oil. J Sci Technol 114: 1-7. DOl: 10.1002/ejilt.201100158.

Yanty NAM, Lai OM, Osman A, Long K, Ghazali HM. 2008. Physicochemical properties of Cucumis melo var. inodorus (honeydew melon) seed and seed oil. J Food Lipids 15: 4255. DOI: 10.1111/j.1745-4522.2007.00101.x. 